13 - ORIGINAL ARTICLE

TECHNICAL SKILL

\title{
New suture techniques for best esthetic skin healing ${ }^{1}$
}

\section{Novas técnicas de suturas para melhor cicatrização estética da pele}

\author{
Otoni Moreira Gomes ${ }^{\mathrm{I}}$, André Silva Campos do Amaral ${ }^{\mathrm{II}}$, Ariel José Villar Gonçalves ${ }^{\mathrm{II}}$, Auro Sérgio Perdigão de Brito ${ }^{\mathrm{II}}$, Ernesto \\ Lentz de Carvalho Monteiro ${ }^{\text {III }}$
}

IFull Professor, Department of Surgery, School of Medicine, UFMG; Scientific Director Sao Francisco de Assis Truth is Jesus Cardiovascular Foundation, Belo Horizonte-MG, Brazil. Main author. Research development, analysis and interpretation of data, manuscript writing, critical revision.

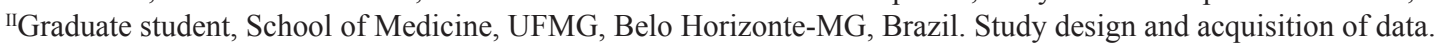

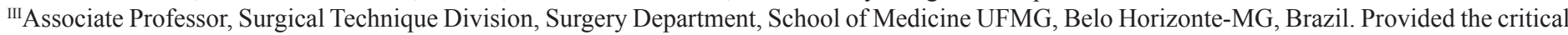
revision of the manuscript.

\begin{abstract}
PURPOSE: To report two new suture techniques for best esthetic skin healing.

METHODS: Using the pig skin slices routinely employed for surgical technique training two new types of skin sutures were performed. One defined as inverted or hidden X point suture and other as totally hidden intradermal running suture. The first were performed using 4-0 polypropilene stitch and the intradermal with 4-0 poliglicolic stitch.

RESULTS: It was confirmed good skin layers union and contention with best esthetic result than observed with the traditional $\mathrm{X}$ and intradermal suture techniques.

CONCLUSION: Macroscopic examination of the hidden X point and totally hidden intra-dermal sutures and centrifuge skin traction confirmed good skin layers union and contention with best esthetic result than observed with the traditional $\mathrm{X}$ and intradermal sutures techniques.
\end{abstract}

Key words: Suture Techniques. Training. Plastic Surgery. Wound Healing. Skin.

\section{RESUMO}

OBJETIVO: Apresentar dois novos tipos de suturas para melhor resultado estético na cicatrização da pele.

METODOS: Utilizando fragmentos de pele de porco rotineiramente empregados no ensino e treinamento de técnica operatória, dois novos tipos de suturas da pele foram desenvolvidos. Um deles definido como sutura com pontos em $\mathrm{X}$ invertidos ou ocultos e outro como sutura intradérmica totalmente oculta. A primeira foi realizada com fio de polipropileno 4-0, e a intradérmica oculta com fio poliglicólico 4-0.

RESULTADOS: Foram confirmados contenção e união adequada das camadas da pele com melhores resultados estético do que observados com as suturas tradicionais em X e intradémica.

CONCLUSÃO: A análise macroscópica das suturas com pontos em X oculto e intradermica totalmente oculta e a tração centrífuga da bordas suturadas confirmaram boa união das camadas da pele com melhor resultado estético do que observado com as suturas em X e intradérmicas tradicionais.

Descritores: Técnicas de Sutura. Capacitação. Cirurgia Plástica. Cicatrização. Pele. 


\section{Introduction}

The register of the development of sutures dates since $3.000 \mathrm{bC}$ with the papyruse of Ebers describing use of the line in the Egypt to close wounds, The use of a categute wire for scarring of a wound had as first citation the comments carried through for Galeno (130 a.C.)., in his work "De Medicina" Cornelius, 53 $\mathrm{aC}-7 \mathrm{dC}$ describes vascular ligatures. It was recovered by order of Pope Nicholas and re-edited in 1478 after the invention of printing by Gutemberg ${ }^{1}$. At the century IX, Rhazes was the first one to use the categute wire in an abdominal suture. In century $\mathrm{X}$, Avicenna evidenced that the hemp was breached in the presence of infection and Ambroise Paré, in century XVI described a way to approach the edges of wounds of the face by means of ribbons, having declared "Nature will do the healing, since the doctor does not disturb its evolution". "John Hunter in century XVIII tells that the suture must be made with separate points and Joseph Lister, in century XIX, considers that the chemical sterilization of wires diminishes the infection and introduces the wire of categute coated with acid chromic ${ }^{3}$.

The manipulation of the wounds, objectifying better results on scarring, has challenged surgeons, whose attitudes have changed over the centuries. In a panoramic analysis, we can identify four stages on the evolution of suture, which are characterized due to peculiar therapeutical measures. In the first, which lasted until the beginning of Christianity, the physician did not propose an intervention other than cleaning the wound and application of honey on it, hoping to wound healing by secondary intention. In mid-1586, Ambroise Pare returned the principle of minimal interference, emphasized in the following sentence: "Nature will do the healing since the doctor does not hinder its development"'.

The second phase may have its onset characterized by the actions of John Hunter, William Halsted and Alexis Carrel, who improved cleaning techniques and the depth of the wounds using sutures for approximation of its edges.

The third phase appeared on century XIX with Semmelweis, Lister and Pasteur, who introduced their principles of antisepsis for the control of the infections, thus facilitating the scarring.

The last phase can be observed in the current days. Thanks to the advent of science, the human being starts to search new ways based on the biotechnology for wounds scarring ${ }^{4}$.

Nevertheless advanced technology is not yet granted to the majority of patients in the mankind, being the surgeon skill the most important factor for the surgery success and patient happiness. In this particular aspect the results of the surgical skin healing plays a very significant role, being the objective of the present article to report two new sutures technique for best esthetic skin healing.

\section{Methods}

This study was approved by the Ethics Committee of our institutions and was conducted using the pig skin slices from meat stores routinely employed for surgical technique training. Two new types of skin sutures were performed. One defined as inverted or hidden X point suture and other as totally hidden intradermal running suture. For this purpose the first was performed using 4-0 polypropilene stitch and the intra-dermal with 4-0 poliglicolic acid stitch

The Figure $1(\mathrm{~A}, \mathrm{~B})$ shows the correct way to do the inverted or hidden $\mathrm{X}$ suture: the needle enters perpendicularly for one of the edges, passes for dermis, reaches dermis of the opposing edge in an oblique direction and leaves for the epidermis. After that, it enters again perpendicular to the skin, in an opposing point to that one of exit (analogous the vertices of a rectangular triangle), passes obliquely in dermis, leaving for the epidermis in a perpendicular point to the first entry point. It ends up tying the free edges of the wire.
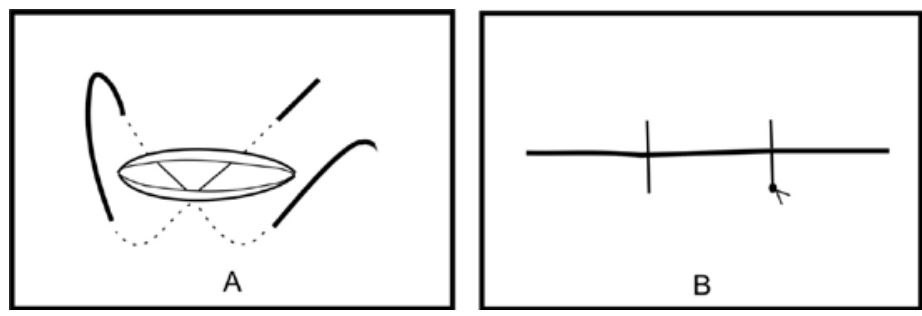

FIGURE 1 - Inverted or hidden X stitch sequence (A,B).

To realize the totally hidden intra-dermal suture (Figure $2 \mathrm{~A}, \mathrm{~B}, \mathrm{C})$ the first step is to divulse dermis of the extremities of the lesion with a scissors. Then we introduce, in the dermis, the needle parallel to the angle of one end of the injury, tying up the knot, that will not be exposed on the surface. After that, it proceeds in a manner identical with that previously exposed, until reaching the other extremity. To finish it, the needle should pass perpendicular to the opening angle of this end, that is, containing all and only the dermis. Finally, it's important tying the knot, to fixing the free ends of the wires. 

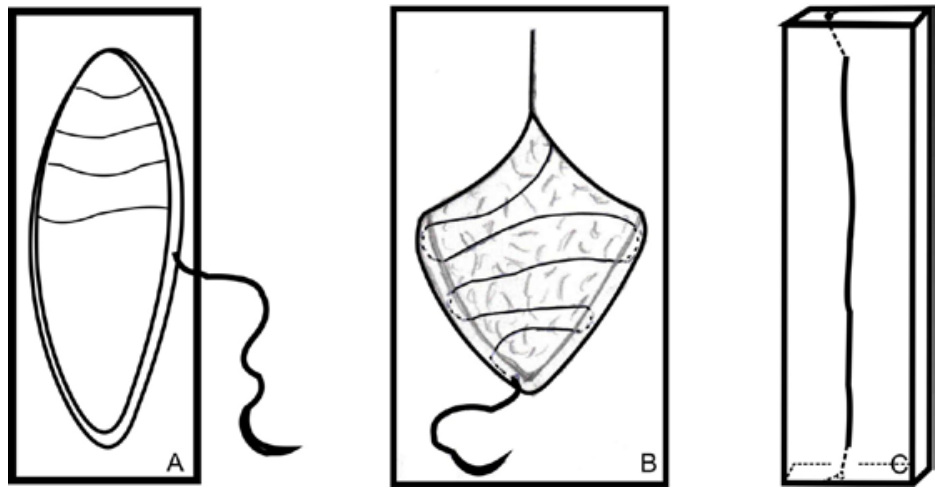

FIGURE 2 - Hidden intradermal suture sequence (A,B,C).

\section{Results}

Macroscopic examination of the hidden X point (Figure 3) and totally hiddent intra-dermal (Figure 4) sutures and centrifuge skin traction confirmed good skin layers union and contention with best esthetic result than observed with the traditional $\mathrm{X}$ and intra-dermal sutures techniques.

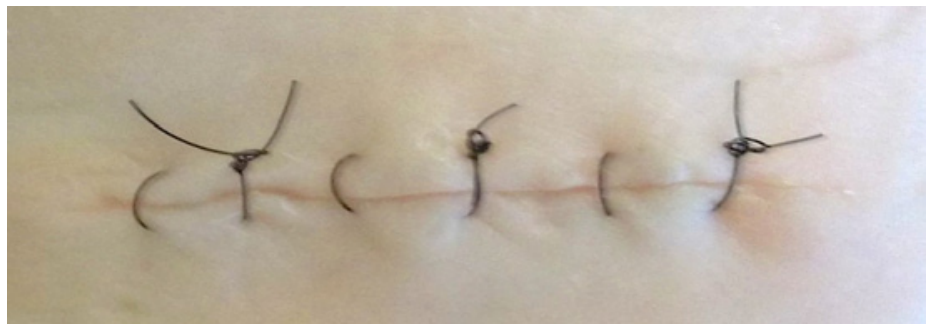

FIGURE 3 - Skin suture with hidden points in X.

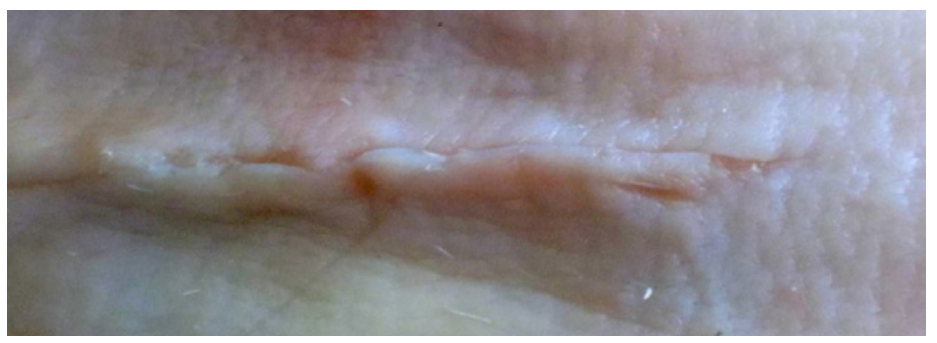

FIGURE 4 - Totally hidden intradermal suture.

\section{Discussion}

Regarding the $\mathrm{X}$ stitch we must recall that it allows greater tension than the simple stitch, the Donatti and the suture with $U$ points. To do it, the needle must pass perpendicularly for the epidermis of one of the edges, reaching dermis of the opposite edge in the same direction, leaving the epidermis. Then it must pass again through the epidermis of the first edge chosen in an obliquely direction (like a diagonal). Again the needle will come out in dermis of the edge in question and will enter in dermis of the opposite edge in the same direction, leaving the epidermis.
Finally, the wire from the free extremities, are tied. However, it is more harmful to the skin healing living a very impressive $\mathrm{X}$ mark visible after the skin healing; while with the proposed inverted or hidden $\mathrm{X}$ suture the skin healing will have only two sequential single points suture scars.

The common Intra-dermal suture notoriously promotes a good synthesis of the skin layers only exposing edges of the first and last suture knots with an excellent aesthetic result. Nevertheless the exposed ends of the suture trough the skin may be a way for bacterial access and subcutaneous infection.

The new totally hidden intradermal suture differs from the common intra-dermal above described basically because of the way it begins and ends without points in the surface of the suture, with best protection against infection complication and best emotional acceptance by the patient not needing any intervention for line or knots removal.

Not withstand the limitation regarding surgical technique studies in dead tissues, the macroscopic examination of the hidden $\mathrm{X}$ point and totally hidden intra-dermal sutures and the centrifuge skin traction test confirmed good skin layers union and contention with best esthetic result than observed with the traditional $\mathrm{X}$ and intra-dermal sutures techniques. Results that are being confirmed in clinical cases of patients submitted to cardiovascular surgery.

\section{Conclusion}

The hidden $\mathrm{X}$ point and totally hidden intradermal sutures promoted good skin layers union and contention with best esthetic result than observed with the traditional $\mathrm{X}$ and intradermal sutures techniques.

\section{References}

1. Kallás IE, Kallás AC, Kallas E. Anastomoses arteriais: passado, presente e futuro. Acta Cir Bras. [serial online] 1999;14(4). Available from: http://www.scielo.br/acb.

2. Braile DM, Godoy MF. História da cirurgia cardíaca. Arq Bras Cardiol. 1996;66(1):330-7.

3. Lister J. The antiseptic principle in the practice of surgery. Lancet. 1867;3:353.

4. Maia JMA, Czeczko NG, Ribas Filho M, Dietz UA, Duck D, Ribas CAPM, Santos EA, Baptistella E, Wallbach TZ, Vale JR, Yagushita N. Estudo da cicatrização de suturas na bexiga urinária de ratos com e sem a utilização de extrato bruto de Jatropha gossypiifolia L. intraperitoneal. Acta Cir Bras. 2006;21:23-30. 


\section{Correspondence:}

Otoni Moreira Gomes

Av. Sanitária Dois, 12

31530-000 Belo Horizonte - MG Brasil

Tel./Fax: (55 31)3439-3004

gomes@servcor.com

Received: February 20, 2011

Review: April 18, 2011

Accepted: May 21, 2011

Conflict of interest: none

Financial source: none

${ }^{1}$ Research performed at Laboratory of Experimental Surgery, School of Medicine, Federal University of Minas Gerais (UFMG) and Experimental Research Laboratory Sao Francisco de Assis Truth is Jesus Cardiovascular Foundation, Belo Horizonte, Brazil. 